\title{
PERANAN AYAM LOKAL DALAM SUDUT PANDANG ADAT BUDAYA BAJAWA NGADA
}

\section{Liliana Regina Deze, Christianus Yoseph Ngiso Bhae}

Program Studi Peternakan Sekolah Tinggi Pertanian Flores Bajawa NTT, Indonesia

Email: lellydeze@gmail.com, tian.ngiso@gmail.com

\begin{abstract}
Abstrak
Ayam lokal atau ayam buras bukan ras dan lebih dikenal dengan sebutan ayam kampung sangat diminati dagingya dan juga telurnya dimana kita ketahui bahwa daging dan telur ayam kampung lebih sehat sehingga konsumsinya terus meningkat. Daging dan telur ayam kampung bukan hanya ditujukan untuk konsumsi keluarga dan masyarakat namun juga memiliki makna ritual dalam acara adat dan upacara keagamaan sesuai dengan kebutuhan. Sistim pemeliharaannya masih semi intensif sehingga pemeliharaannya hanya sekitar halaman rumah. Pemeliharaan ayam kampung di Bajawa Ngada ini masih kecil-kecilan dan kebanyakan masih dilepas dan ayam mencari makan sendiri dan hanya diberi makan pada pagi dan sore hari. Peluang usaha beternak ayam kampung sangat menjanjikan karena masyarakat Bajawa Ngada sangat membutuhkan ayam kampung untuk berbagai acara adat namun cara beternak ayam kampung yang masih tradisional atau semi intensif menjadi salah satu faktor pengahambat usaha ternak ayam kampung untuk mencapai kesuksesan. Tujuan penelitian ini adalah untuk mengenai peranan penggunaan ayam lokal pada sudut pandang adat Budaya Bajawa Ngada. Metode penelitian yang digunakan adalah metode Deskriptif Eksploratif dengan pendekatan wawancara Bersama tokoh adat Bajawa Ngada.Setelah melakukan penelitian ini peneliti mengungkapkan bahwa penggunaan ayam lokal didaerah Bajawa Ngada digemari daan sudah menjadi hal yang memenuhi kebutuhan untuk masyarakat.
\end{abstract}

Kata Kunci: ayam kampung; masyarakat Bajawa; acara adat

\section{Abstract}

Local chickens or buras chickens are not breeds and are better known as chickens are in high demand for meat and eggs where we know that the meat and eggs of kampung chickens are healthier so that their consumption continues to increase. Chicken meat and eggs are not only intended for the consumption of families and communities but also have ritual meaning in traditional events and religious ceremonies according to needs. The maintenance system is still semi intensive so the maintenance is only around the yard. The chickens in Bajawa Ngada are small and most are still released and chickens forage on their own and are only fed in the morning and evening. The business opportunity to raise chickens is very promising because the people of Bajawa Ngada desperately need chicken villages for various customary events but the way to raise village chickens that are still traditional or semi intensive becomes one of the factors inhibiting the effort of chicken farming villages to achieve success. The purpose of this study is to discuss the role of the

$\begin{array}{ll}\text { How to cite: } & \text { Deze. L.R., \& Bhae. C. Y. N., (2021) Peranan Ayam Lokal dalam Sudut Pandang Adat Budaya } \\ & \text { Bajawa Ngada, Syntax Idea, 3(10), https://doi.org/10.36418/syntax-idea.v3i10.1507 } \\ \text { E-ISSN: } & \text { 2684-883X } \\ \text { Published by: } & \text { Ridwan Institute }\end{array}$


use of local chickens in the traditional point of view of Bajawa Ngada Culture. The research method used is an Exploratory Descriptive method with an interview approach with indigenous figures Bajawa Ngada.After conducting this study researchers revealed that the use of local chickens in the Bajawa Ngada area is popular with daan has become a thing that meets the needs for the community.

Keywords: local chicken; Bajawa community; traditional event

\section{Received: 2021-09-22; Accepted: 2021-10-05; Published: 2021-10-20}

\section{Pendahuluan}

Bangsa Indonesia adalah bangsa yang kaya akan budaya dan adat istiadat. Indonesia juga terdiri dari berbagai suku dan masig-masing suku terdapat berbagai bentuk upacara adat sebagai ungkapan rasa syukur kepada leluhur dan alam semesta atas segala berkat kehidupan yang mereka peroleh. Kebudayaan yang dimiliki oleh setiap masyarakat tidak sama, seperti di Indonesia yang terdiri dari berbagai macam suku bangsa yang berbeda, tetapi setiap kebudayaan mempunyai ciri dan sifat yang sama (Wina \& Habsari, 2017). Upacara adat merupakan salah satu bentuk kebudayaan yang berkaitan dengan berbagai fungsi, sehingga mempunyai arti yang sangat penting bagi kehidupan di masyarakat (Rivasintha \& Juniardi, 2017).

Pengetahuan tradisional dan ekspresi budaya tradisional pada keseluruhan pengetahuan dan praktik ekonomi, budaya dan agama yang merupakan sebuah komunitas, dengan menguatkan pandangan ini ada beberapa fungsi unik dalam masyarakat adat yang membutuhkan pertimbangan dari dua fungsi seperti ekonomi, 5 agama, dan masyarakat. Budaya dapat diakses sebagai cerita rakyat dengan penegasan ekonomi dan budaya masyarakat lokal (Masango, 2013).

Adat istiadat yang merupakan sistem norma dan tata kelakuan yang tumbuh dan berkembang di masyarakat secara turun temurun. Di lingkungan masyarakat, adat istiadat sangatlah dijunjung tinggi (Novitasari, 2019).

Sebagaimana masyarakat Bajawa selalu mensyukuri akan segala berkat dan anugerah Tuhan dan leluhur dengan berbagai ritual adat. Kehidupan manusia setiap hari tidak terlepas dari berbagai unsur kebudayaan. Masyarakat Bajawa Ngada masih hidup dalam berbagai adat budaya sejak kelahiran sampai kematian. Kesetiaan mempertahankan dan menjalankan upacara adat tersebut sebagai kesakralan hidup sosial/suku atau simbol kebersamaan merupakan tanggungjawab masyarakat adat.

Untuk ini salah satu unsur penting adalah peranan ternak. Dalam menjalankan berbagai ritual adat ini masyarakat Bajawa membutuhkan ternak sebagai kurban untuk para leluhur. Ternak yang umumnya yang sering digunakan sebagai persembahan untuk leluhur adalah ayam lokal atau ayam kampung. Peranan masyarakat dalam pemanfaatan ayam kampung sebagai pelengkap upacara adat memberikan dukungan besar terhadap eksistensi dan kelestarian ternak ayam kampung. Keunggulan ayam lokal untuk mampu berdaptasi dengan lingkungan tropis dapat memberikan pendapatan yang cukup besar bagi peternak dan ayam lokal dapat dikembangkan sebagai bibit unggul (Siu, 2014). 
Tujuan penelitian ini adalah untuk menjawa seberapa penting ayam lokal menjadi hal untuk menjawab kebutuhan pangan di Bajawa Ngada.

\section{Metode Penelitian}

Metode penelitian ini dengan menggunakan metode kualitatif. Penelitian Kualitatif merupakan Jenis penelitian yang temuan-temuannya tidak diperoleh melalui prosedur statistik atau bentuk hitungan lainnya (Sugiyono, 2013). Pendekatan lainnya adalah observasi lapangan dengan menggunakan metode wawancara dengan tokoh adat.

\section{Hasil dan Pembahasan}

\section{A. Hasil Penelitian}

\section{Gambaran umum masyarakat Bajawa kabupaten Ngada}

Bajawa adalah ibu kota kabupaten Ngada Propinsi Nusa Tenggara Timur yang terletak antara dua kabupaten yaitu kabupaten Nagekeo dan kabupaten Manggrai Timur. Kabupaten Ngada memiliki tiga suku besar yaitu suku Nagekeo, suku Bajawa dan suku Riung. Masing-masing suku ini mempunyai kebudayaan sendiri-sendiri yang masih dipertahankan sampai saat ini, rumah adat, bahasa yang berbeda satu sama lainnya, tarian, pakian adat dan lain-lain (Mali, 2017). Dalam kebudayaan Ngada rumah adat mempunyai peranan yang sangat penting dalam kehidupan sehari hari sebagai simbol penghormatan kepada leluhur yang telah terlebih dahulu hadir di muka bumi. Masyarakat Ngada adalah bagian dari satu rumah adat dan berarti satu marga. Penduduk kabupaten Nagada mayoritas beragama Katolik Roma dan sebagiannya lagi beragama Islam, Portestan dan Hindu. Untuk mata pencaharian penduduk Ngada adalah pegawai negeri sipil (PNS), wiraswasta, nelayan, petani. Sedangkan untuk peternakan hanya pekerjaan sampingan atau sekedar hobi untuk mengisi waktu luang. Hal ini menjadi suatu yang keliru yang harus dirubah karena masyarakat Ngada adalah masyrakat adat yang selalu memberi penghormatan kepada para leluhur dan membutuhkan ternak sebagai hewan kurban. Sebagaimana pengamatan penulis, untuk memenuhi kebutuhan akan ternak dalam menjalankan ritual adat terkadang masyarakat Bajawa harus mendatangkan ternak dari luar daerah bahkan dari luar pulau dan tentunya dengan harga yang cukup tinggi (Djanggo, 2020).

Dari hasil wawancara dengan tokoh adat setempat disampaikan bahwa upacara adat yang dilakukan oleh masyarakat Bajawa tergantung situasi dan kebutuhan misalnya pada saat akan mengikuti kegiatan ujian ataupun kepentingan lainnya, selain memohon kepada Tuhan Yang Maha Esa, masyarakat Bajawa juga meminta dukungan para leluhur dengan istilah adatnya ti'i ka ebu(kasi makan leluhur) dan hewan yang dikurbankan adalah ayam lokal atau ayam kampung jantan.

\section{Keadaan ternak ayam lokal masyrakat Bajawa}

Subsektor peternakan mencakup semua kegiatan pembibitan dan pembudidayaan segala jenis ternak dan unggas untuk tujuan dikembangbiakan, 
dibesarkan, dipotong, atau diambil hasilnya baik yang dilakukan oleh rakyat maupun yang dilakukan oleh perusahaan. Populasi ternak besar yang yang diusahakan oleh masyarakat di Kabupaten Ngada adalah sapi, kerbau dan kuda. Disamping ternak besar masyarakat di Kabupaten Ngada juga mengusahakan ternak kecil dan unggas yaitu kambing, domba, babi, itik dan ayam (Astuti, 2015). Dari berbagai jenis ternak besar yang diusahakan didominasi oleh ternak sapi potong diikuti ternak kerbau sedangkan ternak kecil adalah babi diikuti ternak kambing dan ternak ayam kampung atau ayam lokal.

Ternak ayam kampung atau lokal dibudidayakan oleh setiap keluarga di daerah Bajawa karena mengingat akan peranan ayam kampung yang sangat penting untuk kehidupan sehari-hari. Sebagaimana kehidupan masyarakat Bajawa yang berhubungan erat dengan rumah adat maka dari itu peranan ternak sangat penting teristimewa ayam kampung atau ayam lokal. Simbol budaya yang bermakna dan berperan paling kuat adalah rumah adat. Ia menjadi sentrum dalam hubungan masyarakat.

\section{Upacara adat masyarakat Bajawa}

Tradisi sebagai warisan yang penghormatannya diyakini membawa misi suci karenanya layak dipelihara, pesannya patut diteruskan, amanatnya wajb diingat. Salah satu ternak yang sering digunakan adalah ternak ayam lokal atau ayam kampung. Bagi masyarakat Bajawa ternak ayam lokal sangat dibutuhkan sebagai pelengkap dalam upacara adat. Sedangkan untuk masyarakat Papua keberlangsungan kehidupan tidak lepas dari keberadaan ternak babi. Babi menjadi salah satu ternak yang sangat penting bagi masyarakat Papua dalam berbagai aspek. Berbagai bentuk uapacara yang ada pada umumnya merupakan pencerminan bahwa semua perencanaan, tindakan, perbuatan, telah diatur oleh tata nilai luhur. Tata nilai luhur tersebut telah diwariskan oleh leluhur turun temurun dari generasi ke generasi berikutnya sebagai sebuah tradisi (Nggewaka, 2020). Manusia Bali sejak lahir sampai meninggal memerlukan ayam. "Tapi banyak orang Bali tidak tau maknanya. Ayam energinya besar, baru bangun sudah cari makan," karena energi ini pula, ayam dikomoditaskan di arena-arena sabungan ayam (Suriyani, 2019).

Masyarakat Bajawa hingga kini masih hidup berbagai kebudayaan dan sejumlah upacara tradisional yang berkaitan dengan siklus kehidupan manusia sejak lahir sampe meninggal (Ngebu, 2018). Beberapa upacara tersebut antara lain upacara yang berkaitan dengan kelahiran, upacara pra dewasa (remaja), upacara dewasa, upacara kematian, upacara bercocok tanam, upacara membangun dan masuk rumah adat dan masih ada lagi beberapa upacara adat lainnya yang kesemuanya memohon perlindungan Tuhan Yang Maha Kuasa melalui para leluhur. Dalam setiap ritual adat yang dilakukan semuanya menggunakan ternak ayam lokal atau ayam kampung jantan yang akan disembeli dan dipersembahkan untuk menghormati para leluhur dan juga makan bersama untuk segala urusan perhelatan ritual adat lainnya. Adapun beberapa ternak yang digunakan misalnya 
ternak babi, ternak ruminansia besar (kerbau), tetapi yang paling sering digunakan adalah ternak ayam kampung jantan kesemuanya itu melambangkan kebesaran dan penghormatan tertinggi untuk para leluhur dan juga melambangkan pangkat dan kekayaan dari seseorang.

\section{B. Pembahasan}

Ritual adat yang wajib dilakukan oleh masyarakat Bajawa merupakan warisan para leluhur dan dilanjutkan dari generasi ke generasi karena terdapat banyak manfaat dan fungsi. Setiap hasil kebudayaan mempunyai bentuk, fungsi dan makna baik hasil kebudayaan tertulis, lisan, setengah lisan, maupun bukan lisan. Sebuah upacara adat sebagai hasil kebudayaan apapun bentuknya apabila difungsikan dalam suatu masyarakat maka akan menghasilkan makna (Zawa, 2020).

Kehidupan masyarakat Bajawa Ngada tidak terlepas dari ritual adat, dan masyarakat Bajawa sangat memegang teguh adat budaya karena manfaat serta fungsi dari adat budaya dalam kehidupan setiap hari sembari selalu mengandalkan Tuhan Yang Maha Kuasa (BEO, 2020). Pada saat melakukan upacara adat ini senantiasa menggunakan hewan sebagai kurban untuk para leluhur. Hewan kurban yang sering digunakan misalnya kerbau, babi dan yang paling sering digunakan adalah ayam kampung jantan. Semuanya tergantung jenis upacara adat dan kebutuhan, misalnya upacara adat kematian ataupun upacara ka sa'o (pendinginan rumah adat baru), rebha (tahun baru adat), yang mengumpulkan banyak orang ataupun kerabat dekat maupun jauh, ternak yang digunakan adalah kerbau jantan atau babi jantan. Sedangakan upacara adat yang dilakukan hanya anggota keluarga dalam rumah saja biasanya ternak yang digunakan adalah ayam kampung jantan (Sene, Wandut, \& Nukango, 2021).

Dalam perkembangan jaman saat ini segala jenis upacara adat tidak lagi memandang status sosial ataupun kedudukan melainkan berdasarkan kemampuan ekonomi.

\section{Kesimpulan}

Kehidupan manusia tidak terlepas dari adat budaya yang mana semuanya sebagai ungkapan rasa syukur dan juga permohonan untuk perlindungan kepada para leluhur pada kehidupan di hari hari seanjutnya selain ke hadapan Tuhan Yang Maha Esa. Dalam melaksanakan berbagai ritual adat ini tentunya menggunakan hewan sebagai kurban untuk para leuhur dan sebagai penyatuan dengan alam semesta. Kesemuanya sesuai dengan adat dan tradisi daerah masing-masing dan disesuaikan dengan kebutuhan dari acara ritual adat tersebut. Ternak ayam kampung jantan sering digunakan dalam ritual adat. Sebagaimana masyarakat Bajawa Ngada yang merupakan bagian dari satu rumah adat dan berarti satu marga sehingga sering melakukan ritual adat dalam kehidupan setiap hari dan sesuai dengan kebutuhan. 


\section{BIBLIOGRAFI}

Astuti, Riska Dwi. (2015). Analisis Determinan Ketimpangan Distribusi Pendapatan di Daerah Istimewa Yogyakarta Periode 2005-2013. Tirtayasa Ekonomika, 15(1), 1730.Google Scholar

BEO, Lukas Elminaldo. (2020). Makna Ritus Nggua Keu Uwi Pada Masyarakat Adat Detukeli Dalam Perbandingan Dengan Ajaran Gereja Katolik Tentang Ekaristi Dan Implikasinya Terhadap Karya Pastoral Gereja. STFK Ledalero. Google Scholar

DJANGGO, Albertus Dau. (2020). Ritus Adat Na'a Wi Lika Pada Masyarakat Nuamuzi Dan Relevansi Nilai-Nilainya Bagi Keluarga Katolik. STFK Ledalero. Google Scholar

Mali, Fransiskus X. Gian Tue. (2017). Konflik Tanah Di Daerah Otonom Baru (Dob) Studi Konflik Tanah Pembangunan Kantor Dprd Di Kabupaten Nagekeo, Provinsi Nusa Tenggara Timur. Sociae Polites, 18(01), 39-56. Google Scholar

Masango, Johannes Mboneni. (2013). The roles of the principal and the SBST in supporting teachers teaching inclusive education. University of Pretoria. Google Scholar

Ngebu, Johanis Fiani. (2018). Pendidikan Karakter dalam Kosmologi Masyarakat Suku Bajawa di Flores-Nusa Tenggara Timur. Seminar Nasional GEOTIK 2018. Google Scholar

Nggewaka, Antonius. (2020). Dimensi Fungsional Upacara Ndambu Pada Masyarakat Malind Suku Kima-Ghima Di Distrik Kimaam Kabupaten Merauke Provinsi Papua. Universitas Hasanuddin. Google Scholar

Novitasari, Richa Dwi. (2019). Lunturnya Adat Istiadat Dan Sosial Budaya Berdasarkan Unsur Pancasila. Google Scholar

Rivasintha, Emusti, \& Juniardi, Karel. (2017). Pergeseran nilai-nilai budaya dalam upacara adat gawai dayak ditinjau dari sosial ekonomi masyarakat kota pontianak. Sosial Horizon: Jurnal Pendidikan Sosial, 4(1), 1-10. Google Scholar

Sene, Mikael, Wandut, Wilhelmina Kurnia, \& Nukango, Anjelina Jama. (2021). Praktik Kepercayaan Marapu Yang Masih Dilaksanakan Oleh Umat Katolik Di Paroki Hati Kudus Yesus Weekombaka, Kabupaten Sumba Barat Daya. Atma Reksa: Jurnal Pastoral Dan Kateketik, 4(2), 4-23. Google Scholar

Siu, Hendrikus Primus. (2014). Nilai Dan Simbol Religius Perjamuan Raya (Nado Mere) Masyarakat Jawawawo. Jurnal Masalah Pastoral, 3(1), 22. Google Scholar

Sugiyono. (2013). Metode Penelitian Kuantitatif Kualitatif dan R\&D. Bandung: CV Alfabeta. Google Scholar 
Liliana Regina Deze, Christianus Yoseph Ngiso Bhae

Suriyani, L. D. (2019). Makna Pentingnya Ayam Dalam Hidup Orang Bali.

Wina, Priani, \& Habsari, Novi Triana. (2017). Peran Perempuan Dayak Kanayatn Dalam Tradisi Upacara Naik Dango (Studi Di Desa Padang Pio Kecamatan Banyuke Hulu Kabupaten Landak Kalimantan Barat). Agastya: Jurnal Sejarah Dan Pembelajarannya, 7(01). Google Scholar

Zawa, Artemius. (2020). Makna Perkawinan Adat Bagi Kehidupan Sosial Masyarakat Wangka. STFK Ledalero. Google Scholar

\section{Copyright holder:}

Liliana Regina Deze, Christianus Yoseph Ngiso Bhae (2021)

\section{First publication right:}

Syntax Idea

This article is licensed under:

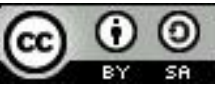

